\title{
Multiple primary malignancies in osteosarcoma patients. Incidence and predictive value of osteosarcoma subtype for cancer syndromes related with osteosarcoma
}

\author{
EI Hauben ${ }^{1,2,5}$, J Arends ${ }^{2}, \mathrm{JP}$ Vandenbroucke ${ }^{3}$, CJ van Asperen ${ }^{4}$, E Van Marck ${ }^{5}$ and \\ PCW Hogendoorn*,2
}

\footnotetext{
${ }^{1}$ Laboratory for Pathology, Stichting PAMM, Eindhoven, The Netherlands; ${ }^{2}$ Department of Pathology, Leiden University Medical Centre, Leiden, The Netherlands; ${ }^{3}$ Department of Epidemiology, Leiden University Medical Centre, Leiden, The Netherlands; ${ }^{4}$ Department of Clinical Genetics, Leiden University Medical Centre, Leiden, The Netherlands; ${ }^{5}$ Department of Pathology, University of Antwerp, Belgium
}

The overall incidence of osteosarcoma is low. However, the occurrence of osteosarcoma in a setting of multiple primary tumours is not infrequent, although population-based incidence numbers are unknown. The occurrence of osteosarcoma and other malignancies is frequently related to treatment, and can also be the result of genetic predisposition as in patients with retinoblastoma, Li-Fraumeni syndrome, Werner syndrome and Rothmund-Thomson syndrome. The aim of our study is to establish the incidence of osteosarcoma associated with other malignancies in a populationwide study and to find out if these osteosarcomas have a specific subtype, that could draw attention to a genetic predisposition to malignancy. A list of all patients registered in the Dutch National Pathology Register, named PALGA, with a diagnosis of osteosarcoma between 1975 and May 2000 was retrieved. All patients with another malignancy besides osteosarcoma were selected. All patients registered in the same period with a tonsillectomy served as a control for the occurrence of malignancy in a normal population. In a second step, only osteosarcoma patients with a history of retinoblastoma or a malignancy before the age of 46 years, since these are most probable to have a hereditary cancer syndrome, were retained for further analysis. The osteosarcomas were subtyped as common, chondroblastic, fibroblastic, teleangiectatic, anaplastic, osteoclast-rich or small cell. As a control for osteosarcoma subtypes the data of $\mathbf{5 7 0}$ patients entered in two studies from the European Osteosarcoma Intergroup (EORTC/MRC) were used. Of all 938 patients registered with the diagnosis of osteosarcoma, 66 had a history of multiple primary tumours. Four patients had a surface osteosarcoma, three an extraskeletal osteosarcoma and 59 had intramedullar highgrade osteosarcoma. Of this last group, one patient was known with Rothmund-Thomson syndrome, one had retinoblastoma and 30 had their malignancies before the age of 46 . Of these 32 patients, 17 had osteosarcoma of the long bones. Especially women seem to be more susceptible for the development of multiple primaries. In nine patients, the histological subtype could be assessed by revision of available histological slides. All of these patients had an osteosarcoma subtype other than common as opposed to $\mathbf{2 9 \%}$ in the control group of the European Osteosarcoma Intergroup. It is concluded that although the

\footnotetext{
*Correspondence: Dr PCW Hogendoorn, Department of Pathology, Leiden University Medical Centre, PO Box 9600, 2300 RC Leiden, The Netherlands. Tel: +31 7152666 39; Fax: +31 7152481 58;

E-mail: P.C.W.Hogendoorn@lumc.nl

Received 23 July 2002; revised 7 March 2003; accepted 17 March 2003
} 
incidence of osteosarcoma is low, the occurrence of another malignancy in osteosarcoma patients is higher than in the normal population. Specifically, osteosarcoma patients have a relative risk of $2.4(95 \%$ confidence interval 1.88-3.07) to develop another malignancy. A noncommon subtype of osteosarcoma should draw attention to a possible genetic predisposition of the patient involved. European Journal of Human Genetics (2003) 11, 611-618. doi:10.1038/sj.ejhg.5201012

Keywords: osteosarcoma; histological subtype; hereditary cancer; second malignancy; human genetics

\section{Introduction}

Osteosarcoma is the most frequent nonhaematogenic malignant bone tumour. ${ }^{1-3}$ Central high-grade osteosarcoma accounts for approximately $20-22 \%$ of all primary malignant bone tumours. Although the overall incidence of osteosarcoma is low, osteosarcoma is one of the most frequent tumours associated with other malignancies. Aetiology is multifactorial. Case reports on second malignancies including osteosarcoma after radiation or chemotherapy treatment in cohorts of patients with cancer in childhood and adolescence are many. These studies have been substantially reviewed by Cullen and Meadows. ${ }^{4,5}$ The occurrence of multiple primary tumours including osteosarcoma can also be the result of genetic predisposition as is the case in retinoblastoma ${ }^{6-13}$ and the Li-Fraumeni syndrome. ${ }^{14,15}$ There is also an elevated risk for osteosarcoma in Werner syndrome ${ }^{16-18}$ and Rothmund-Thomson syndrome. ${ }^{19}$ Data on syndrome-related osteosarcoma patients are mostly calculated from clusters and families of patients already diagnosed with a specific genetic syndrome and thus give no indication of the incidence of hereditary cancer syndromes including osteosarcoma in a population. Based on histological criteria, osteosarcomas can be subtyped as common, chondroblastic, teleangiectatic, fibroblastic, small cell, giant cell rich and sclerotic/osteoblastic. The histological subtype of osteosarcoma is a predictive factor for response to chemotherapy, $^{20,21}$ is related with disease-free survival ${ }^{22}$ and tends to be related with overall survival. ${ }^{21}$

In order to have an estimate of the number of osteosarcoma patients with a possible hereditary cancer syndrome in a population, we studied all patients with high-grade intramedullar osteosarcoma, who either had a retinoblastoma in the antecedents or any other primary tumour at a relative young age.

In addition, we were interested to see if osteosarcoma subtypes reflect a possible hereditary background for malignancy.

\section{Material and methods Database \\ Listings of all patients between 1975 and the 20th of May 2000 diagnosed with osteosarcoma were obtained through}

the national computerised pathology records system of Foundation PALGA (The Dutch National Pathology Registry). The PALGA registration is obligatory for all pathology labs in the Netherlands. It contains the full conclusions of the pathology report and includes as such all histological and cytological and autopsy data for every patient in the Netherlands. This registration started in 1975 and reached 100\% participation of all pathology labs since 1990. This database serves for several populationbased questions and forms among others the database source for the Dutch Cancer Registry.

All patients with a reliable diagnosis of osteosarcoma and any other primary tumour, not carcinoma in situ, were selected for further investigation.

\section{Selection of syndrome-suspected study group}

The syndrome-suspected study group was composed of all osteosarcoma patients with one of the following criteria: (1) a medical history of retinoblastoma; (2) a primary tumour diagnosed before the age of 46 years, since $70 \%$ of the $\mathrm{Li}$-Fraumeni patients are at risk to develop a second primary malignancy after a first primary before that age; ${ }^{23}$ (3) patients with carcinoma of the skin before the age of 44 years. This age was chosen as a cutoff, since only $4 \%$ of all squamous cell carcinomas of the skin and only $10 \%$ of all basal cell carcinomas of the skin occur before the age of 44 as has been shown by a study covering the region of southeast Netherlands. ${ }^{24}$ Of these patients all available patient data and histological material were reviewed.

\section{Review and classification}

Subtyping of the osteosarcomas was performed by two review pathologists of the European Osteosarcoma Intergroup (PCWH and $\mathrm{EH}$ ). Osteosarcomas were classified as conventional, chondroblastic, teleangiectatic, small cell, fibroblastic, osteoclast rich, anaplastic and sclerotic/osteoblastic well differentiated, as defined by the established criteria. $^{25-30}$

\section{Control groups}

As a control for the occurrence of malignancy served 23252 patients with tonsillectomy diagnosed in the same study period (database interval) as the osteosarcoma patients. Using this control group from the same database, instead of computing an expected number of carcinomas 
in the general population, has several important advantages. The selection of patients with osteosarcoma is the same as the selection of the control group, coming from the same group of pathology labs, so that potential regional differences in completeness of adherence of pathology laboratories to the database are levelled out. Moreover, it is not clear how 'person-years' should be calculated, since the survival of the patients with the primary tumours in the database is not known. Patients with lymphoma or malignancy in the head and neck region, in which tonsillectomy is part of the diagnostic work up or treatment, were excluded in order to avoid selection bias. We adjusted the relative risk calculation for age and sex by use of a Mantel-Haenszel procedure.

As control for subtype the histological data from the first two studies of the EORTC, including 570 patients, were used. $^{21}$ The distribution of the subtypes in this group is comparable to that of a similar study group of the Rizzoli Institute. $^{20}$

\section{Results}

Osteosarcoma in the Netherlands

According to the data obtained from PALGA, 938 patients, 513 male and 425 female, were diagnosed with osteosarcoma between 1975 and May 2000. Age varied from less than
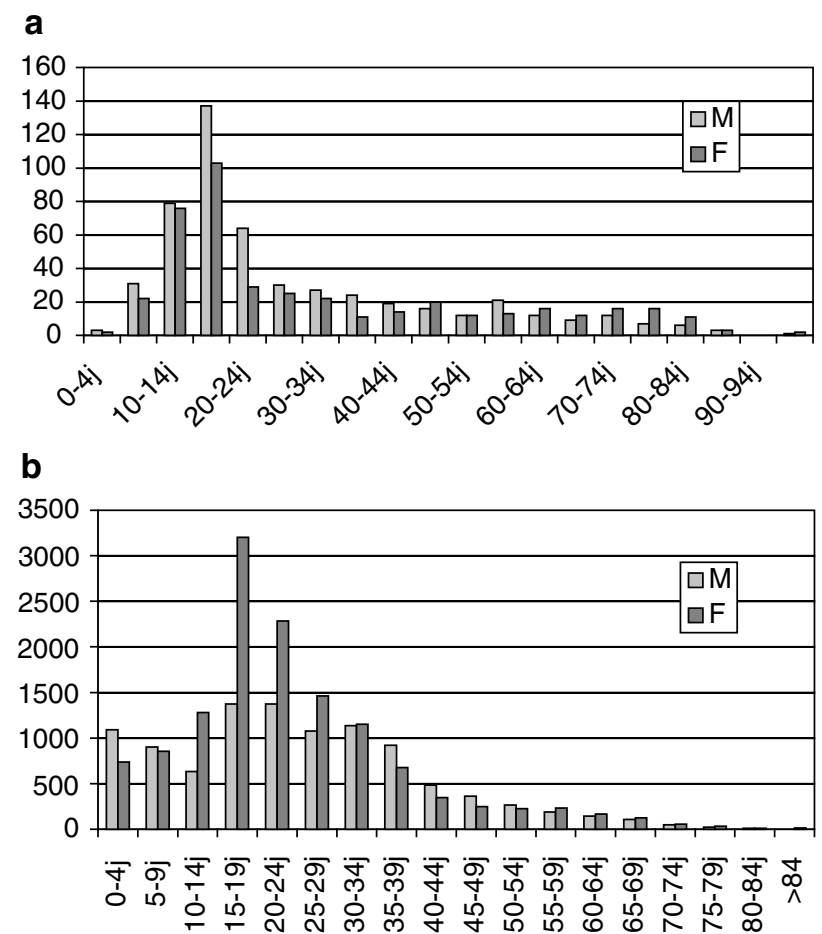

Figure 1 (a) Number of osteosarcoma patients by age as found in the nationwide survey $(n=938)$. (b) Number of tonsillectomy patients by age $(n=23252)$.
Table 1 Localisation of osteosarcoma by gender

\begin{tabular}{lrrr}
\hline & $M$ & $F$ & \\
\hline Intramedullar osteosarcoma extremity & 374 & 281 & \\
Intramedullar osteosarcoma axial skeleton & 87 & 97 & \\
Surface OS & 25 & 26 & \\
Extra skeletal OS & 27 & 21 & \\
Total & 513 & 425 & 938 \\
\hline
\end{tabular}

Table 2 Localisation of osteosarcoma in patients with other malignancies

\begin{tabular}{lrrr}
\hline & $M$ & $F$ & \\
\hline Intramedullar osteosarcoma extremity & 9 & 17 & \\
Intramedullar osteosarcoma axial skeleton & 13 & 20 & \\
Surface OS & 2 & 2 & \\
Extra skeletal OS & 0 & 3 & \\
Total & 24 & 42 & 66 \\
\hline
\end{tabular}

1 year to 99 years with a mean of 20 years. Distribution per age group is given in Figure 1 and distribution by localisation in Table 1.

\section{Patients with multiple primary malignancies including osteosarcoma}

A total of 66 osteosarcoma patients (7\%) had another malignancy, 24 male $(5 \%$ of the male osteosarcoma patients) and 42 female (10\% of the female osteosarcoma patients) (Table 2). These 66 patients had a total of 73 other malignancies. Multiple basal cell carcinomas in a given patient were counted as one. The nature of these other malignancies is summarised in Table 3. Thirty-five patients had their malignancy prior to osteosarcoma, 31 after. The interval ranged from 0 to 264 months with an average of 92 months prior to the diagnosis of osteosarcoma and 0-231 months with an average of 79 months after the diagnosis of osteosarcoma. In patients with osteosarcoma and another malignancy, the osteosarcomas were more frequently localised in flat bones, bones of the skull and axial skeleton (Table 4). In all, 18\% of the patients with intramedullar osteosarcoma of the skull and axial skeleton had other malignancies in contrast to $4 \%$ of the patients with osteosarcoma of the long bones of the extremity.

In the control group of 23252 , tonsillectomy patients, 10142 men and 13110 women (age distribution in Figure 1), 383 (1.6\%) had a malignancy in the observed interval of 120 months before or after tonsillectomy. The crude relative risk of developing a malignancy in osteosarcoma patients is 4.4. After adjustment for age and sex, the relative risk is 2.4 (95\% confidence interval 1.88-3.07). 
Table 3 Nature of the second neoplasm besides osteosarcoma

\begin{tabular}{|c|c|c|c|c|}
\hline Other malignancy & $\begin{array}{l}M<45 \\
\text { years }\end{array}$ & $\begin{array}{l}M \geqslant 45 \\
\text { years }\end{array}$ & $\begin{array}{l}F<45 \\
\text { years }\end{array}$ & $\begin{array}{l}F \geqslant 45 \\
\text { years }\end{array}$ \\
\hline Hodgkin's disease & 2 & & & 1 \\
\hline Haematogenic diseases & 1 & & 2 & \\
\hline $\begin{array}{l}\text { Non-Hodgkin's } \\
\text { lymphoma }\end{array}$ & 1 & & 1 & 2 \\
\hline Basal cell carcinoma skin & 1 & 5 & & 6 \\
\hline $\begin{array}{l}\text { Squamous carcinoma } \\
\text { skin }\end{array}$ & & & & 1 \\
\hline $\begin{array}{l}\text { Malignant melanoma } \\
\text { skin }\end{array}$ & & & 1 & \\
\hline $\begin{array}{l}\text { Squamous cell carcinoma } \\
\text { nose }\end{array}$ & & & 1 & \\
\hline $\begin{array}{l}\text { Squamous carcinoma } \\
\text { pharynx/larynx }\end{array}$ & & 2 & 1 & \\
\hline $\begin{array}{l}\text { Adenocystic carcinoma } \\
\text { palate }\end{array}$ & & & 1 & \\
\hline $\begin{array}{l}\text { Muco-epidermoid } \\
\text { carcinoma parotid }\end{array}$ & & & 1 & 1 \\
\hline Hepatocellular carcinoma & & & & 1 \\
\hline Adenocarcinoma lung & & 1 & & \\
\hline $\begin{array}{l}\text { Squamous carcinoma } \\
\text { lung }\end{array}$ & & 1 & & \\
\hline $\begin{array}{l}\text { Signet ring cell } \\
\text { carcinoma stomach }\end{array}$ & & 2 & & \\
\hline $\begin{array}{l}\text { Adenocarcinoma large } \\
\text { intestine }\end{array}$ & & & & 3 \\
\hline Renal cell carcinoma & & 2 & & \\
\hline $\begin{array}{l}\text { Urothelial carcinoma } \\
\text { bladder }\end{array}$ & & 1 & & \\
\hline $\begin{array}{l}\text { Prostatic } \\
\text { adenocarcinoma }\end{array}$ & & 1 & & \\
\hline Ductal carcinoma breast & & & 2 & 5 \\
\hline $\begin{array}{l}\text { Squamous carcinoma } \\
\text { cervix uteri }\end{array}$ & & & & 1 \\
\hline Endometrioid carcinoma & & & & 1 \\
\hline Ovarian carcinoma & & & 1 & \\
\hline $\begin{array}{l}\text { Embryonal cell carcinoma } \\
\text { ovary }\end{array}$ & & & 1 & \\
\hline Teratoma testis & 1 & & & \\
\hline Oligodendroglioma & 1 & & & \\
\hline $\begin{array}{l}\text { Papillary carcinoma } \\
\text { thyroid gland }\end{array}$ & & & 1 & \\
\hline Fibrosarcoma & & 1 & 1 & \\
\hline Leiomyosarcoma & & & 1 & 1 \\
\hline Rhabdomyosarcoma & 1 & & & \\
\hline Ewing's sarcoma & 1 & & 2 & \\
\hline Liposarcoma & & & & 1 \\
\hline Nephroblastoma & & & 1 & \\
\hline Retinoblastoma & & & 2 & \\
\hline Unknown & & & 3 & 1 \\
\hline
\end{tabular}

\section{Syndrome-suspected study group}

After selection of all patients with intramedullar osteosarcoma and a history of bilateral retinoblastoma, carcinoma of the skin before 44 years of age or any primary tumour till the age of 45 years, a group of 31 patients remained. One patient with known Rothmund-Thomson syndrome was also included. The data of these 32 patients are summarised in Table 5. In the syndrome-suspected study group without relation to treatment patients with other malignancies
Table 4 Proportion of osteosarcomas by localisation with and without other malignancies

\begin{tabular}{|c|c|c|c|c|}
\hline \multirow[b]{2}{*}{$\begin{array}{l}\text { Intramedullar } \\
\text { osteosarcoma } \\
\text { extremity }\end{array}$} & \multicolumn{2}{|c|}{$\begin{array}{c}\text { Osteosarcoma } \\
\text { only }\end{array}$} & \multicolumn{2}{|c|}{$\begin{array}{c}\text { Osteosarcoma+ } \\
\text { other }\end{array}$} \\
\hline & 655 & $70 \%$ & 26 & $39 \%$ \\
\hline $\begin{array}{l}\text { Intramedullar } \\
\text { osteosarcoma axial } \\
\text { skeleton }\end{array}$ & 184 & $20 \%$ & 33 & $50 \%$ \\
\hline Surface OS & 51 & $5 \%$ & 3 & $4,5 \%$ \\
\hline Extra skeletal OS & 48 & $5 \%$ & 3 & $4,5 \%$ \\
\hline Total & 938 & $100 \%$ & 67 & $100 \%$ \\
\hline
\end{tabular}

represented $2 \%$ of the patients with osteosarcoma of the long bones and $2 \%$ of the patients with osteosarcoma of the bones of the skull and axial skeleton. Thus, the observed over-representation of osteosarcoma of flat bones and bones of the axial skeleton in patients with other malignancies was not seen anymore in the syndromesuspected study group.

The patient data and histological material from contributory departments of pathology all over the Netherlands were reviewed. From 20 patients histological material was available for review and analysis (Table 6). Ethics and privacy guidelines concerning the use of patient files made it impossible to obtain additional data on patients and treatment modalities outside the pathology protocol that was sent in with the histological material.

In the total group of 32 of patients, eight patients developed an osteosarcoma at the site of previous radiation therapy, one patient had lymphoma and one myelodysplastic syndrome after chemotherapy for osteosarcoma. In 14 patients (case numbers in bold), we could make sure that there was no relation with therapy between primary and secondary tumour. One of these patients was known with Rothmund-Thomson, one had a basal cell carcinoma and the remaining 12 patients potentially belonged to a $\mathrm{Li}$ Fraumeni (-like), or other not yet defined cancer syndrome family.

\section{Osteosarcoma subtypes in syndrome-suspected osteosarcoma patients}

All of the patients in our final selection of osteosarcoma patients with high-grade intramedullar osteosarcoma suspected of a genetic cancer syndrome, and from which material was present for review (Table 7), had an osteosarcoma subtype other than common as opposed to $29 \%$ in the control group (Table 8).

\section{Discussion}

Data on osteosarcoma in occurrence with other malignancies come to us by large follow-up studies on late effects 
Table 5 Syndrome-suspected study group

\begin{tabular}{|c|c|c|c|c|c|}
\hline No. & Primary tumour & Localisation & Therapy & Secondary tumour & Localisation \\
\hline 118 & Osteosarcoma & Femur & NA & Squamous cell carcinoma & Larynx \\
\hline 120 & Osteosarcoma & Cervical vertebra & S, RT & Adenocarcinoma & Kidney \\
\hline 121 & Osteosarcoma & Cervical vertebra & S, RT & Adenocarcinoma & Kidney \\
\hline 153 & Morbus Hodgkin & Neck & RT & Osteosarcoma & Clavicle \\
\hline 162 & Osteosarcoma & Femur & S, RT & Basal cell carcinoma & Back \\
\hline 173 & Teratoma & Testis & S, RT & Osteosarcoma & Vertebra \\
\hline 196 & Osteosarcoma & Fibula & NA & Plasmocytoma & Ileum \\
\hline 217 & Oligodendroglioma & Brain & S, RT & Osteosarcoma & Skull \\
\hline 247 & Unknown & Unknown, & RT & Osteosarcoma & Tibia \\
\hline 299 & Rhabdomyosarcoma & Maxilla & Ratchet & Osteosarcoma & Palatum \\
\hline 307 & Ewing's sarcoma & Humerus & NA & Osteosarcoma & Humerus \\
\hline 529 & Lymphoma & Abdomen & ChT & Osteosarcoma & Maxilla \\
\hline 732 & Osteosarcoma & Femur & NA & Ductal carcinoma & Breast \\
\hline 734 & Osteosarcoma & Sternum & NA & Ductal carcinoma & Breast \\
\hline 776 & Osteosarcoma & Jaw & NA & Morbus Hodgkin & Axilla \\
\hline 790 & Adenocystic carcinoma & Palatum & S, RT & Osteosarcoma & Jaw \\
\hline 791 & Fibrosarcoma & Breast & NA & Osteosarcoma & Rib \\
\hline 803 & Unknown & Unknown & RT & Osteosarcoma & Rib \\
\hline 808 & Unknown & Unknown & RT & Osteosarcoma & Clavicle \\
\hline 809 & Osteosarcoma & Tibia & NA & Mucinous carcinoma & Ovary \\
\hline 883 & Osteosarcoma & Tibia & S; RT & Ductal carcinoma & Breast \\
\hline 897 & Osteosarcoma & Femur & NA & Melanoma & Arm \\
\hline 906 & Leiomyosarcoma & Cervix & NA & Osteosarcoma & Femur \\
\hline 911 & Nephroblastoma & Kidney & NA & Osteosarcoma & Rib \\
\hline 912 & Ewing's sarcoma & Humerus & NA & Osteosarcoma & Humerus \\
\hline 971 & Osteosarcoma & Femur & $\mathrm{S}, \mathrm{ChT}$ & Ductal carcinoma & Breast \\
\hline 1035 & Osteosarcoma & Femur & $\mathrm{S}, \mathrm{ChT}$ & Lymphoma & \\
\hline 1039 & Osteosarcoma & Femur & $\mathrm{S}, \mathrm{ChT}$ & MDS & \\
\hline 1058 & Osteosarcoma & Fibula & $\mathrm{S}, \mathrm{ChT}$ & Squamous cell carcinoma & Tongue \\
\hline $1107^{a}$ & Osteosarcoma & Tibia & NA & & \\
\hline 1125 & Osteosarcoma & Femur & NA & Leukaemia & \\
\hline 1148 & Retinoblastoma & Eye & S, RT & Osteosarcoma & Nose \\
\hline
\end{tabular}

aPatient known with Rothmund-Thomson.

NA: information not available; S: surgery; RT: radiation therapy; Cht: chemotherapy.

in patients treated for cancer in childhood. With the exception of the study by Hawkins et al, ${ }^{10}$ all these studies are multicentre studies.

We present here the incidence of osteosarcoma patients with other malignancies in a population-based study in the time frame of 1975 to May 2000. Of all patients with a reliable diagnosis of osteosarcoma, $7 \%$ had other malignancies. The relative risk is 2.4 for developing a second malignancy other than osteosarcoma. 3.4\% developed their second tumour after treatment for OS. This equals more or less the finding of $2.6 \%$ in the studies of Pratt ${ }^{31}$ and Longhi ${ }^{32}$. In two other studies this number is, respectively, 1.5 and $5 \% .{ }^{33,34}$ In all, $3.6 \%$ of the osteosarcoma patients presented with osteosarcoma after a previous malignancy. In large studies on late effects of cancer treatment in childhood this is $0.07-0.34 \% .{ }^{10,35-37}$ Especially women seem to be more susceptible to multiple primary tumours. Also in a recent report from the Childhood Cancer Survivor Study, ${ }^{38}$ the female sex proved to be an independent risk factor for the development of second primary tumour.
Most of the follow-up studies on childhood cancer deal with the effects of treatment. For all these studies together the most frequent malignancy after osteosarcoma is leukaemia (36\%). Radiation therapy is the most important causative factor for the development of osteosarcoma. ${ }^{10,11}$ However, alkylating agents and radiation therapy are not the sole causes for malignancies associated with osteosarcoma. Abramson ${ }^{8}$ described an elevated risk for developing osteosarcoma in patients with retinoblastoma not only in the radiation field, but also outside the radiation field and in patients not treated with radiation therapy. This genetic predilection for retinoblastoma patients to develop osteosarcoma was elucidated by the detection of $13 q$ losses ( $\mathrm{Rb}$ gene location) in osteosarcoma developing after hereditary as well as sporadic retinoblastoma, ${ }^{39}$ and in some osteosarcomas in nonretinoblastoma patients. ${ }^{40}$

In our 938 osteosarcoma patients, two had a history of retinoblastoma, one developed osteosarcoma of the nose in the field of previous radiation and at the age of 21 years, one had Ewing's sarcoma of the head of the fibula treated with chemotherapy and radiation therapy 13 years after 
Table 6 Osteosarcoma subtypes in the syndrome-suspected group

\begin{tabular}{|c|c|c|c|}
\hline Subtype & No. & Primary tumour & $\begin{array}{l}\text { Secondary } \\
\text { tumour }\end{array}$ \\
\hline Teleangiectatic & 120 & Osteosarcoma & Adenocarcinoma \\
\hline Teleangiectatic & 121 & Osteosarcoma & Adenocarcinoma \\
\hline Teleanqiectatic & 808 & Unknown & Osteosarcoma \\
\hline Chondroblastic & 153 & Morbus Hodgkin & Osteosarcoma \\
\hline Chondroblastic & 776 & Osteosarcoma & $\begin{array}{l}\text { Morbus } \\
\text { Hodgkin }\end{array}$ \\
\hline Chondroblastic & 911 & Nephroblastoma & Osteosarcoma \\
\hline Fibroblastic & 162 & Osteosarcoma & $\begin{array}{l}\text { Basal cell } \\
\text { carcinoma }\end{array}$ \\
\hline Fibroblastic & 247 & Unknown & Osteosarcoma \\
\hline Fibroblastic & 897 & Osteosarcoma & Melanoma \\
\hline Fibroblastic & 1039 & MDS & Osteosarcoma \\
\hline Fibroblastic & 1107 & Osteosarcoma & \\
\hline $\begin{array}{l}\text { Fibro/ } \\
\text { chondroblastic }\end{array}$ & 971 & Osteosarcoma & $\begin{array}{l}\text { Ductal } \\
\text { carcinoma }\end{array}$ \\
\hline Osteoclast rich & 1058 & $\begin{array}{l}\text { Squamous cell } \\
\text { carcinoma }\end{array}$ & Osteosarcoma \\
\hline Osteoma-like & 529 & Lymphoma & Osteosarcoma \\
\hline Common & 217 & Óligodendroglioma & Osteosarcoma \\
\hline Common & 299 & Rhabdomyosarcoma & Osteosarcoma \\
\hline Common & 790 & $\begin{array}{l}\text { Adenocystic } \\
\text { carcinoma }\end{array}$ & Osteosarcoma \\
\hline Common & 1035 & Lymphoma & Osteosarcoma \\
\hline Common & 1125 & Leukaemia & Osteosarcoma \\
\hline Common & 1148 & Retinoblastoma & Osteosarcoma \\
\hline
\end{tabular}

Table 7 Osteosarcoma subtypes in the syndrome-suspected group without any clear relation with therapy

\begin{tabular}{lccc}
\hline Osteosarcoma subtype & Case No. & & \\
\hline Teleangiectatic & 120,121 & 2 & $22 \%$ \\
Fibroblastic & $162,897,1107$ & 3 & $33 \%$ \\
Fibro/chondroblastic & 971 & 1 & $11 \%$ \\
Chondroblastic & 911 & 1 & $11 \%$ \\
Osteoma-like & 529 & 1 & $11 \%$ \\
Osteoclast rich & 1058 & 1 & $11 \%$ \\
Total & & 9 & \\
\hline
\end{tabular}

bilateral retinoblastoma. This patient subsequently had a mucoepidermoid carcinoma of the parotid gland at 30 years, an extraskeletal osteosarcoma at 31 years in the field of previous radiation on the fibula and a squamous cell carcinoma of the concha medialis of the nose at 34 years.

A second hereditary cancer syndrome in which osteosarcoma is seen is the Li-Fraumeni syndrome. Based on our selection criteria, ${ }^{12}$ patients of all osteosarcoma patients were suspect for having a Li-Fraumeni syndrome, LiFraumeni-like syndrome or another yet undefined hereditary cancer syndrome. The way we conducted our research, all data were anonymous. Therefore no family histories could be obtained. This makes the application of the
Table 8 Osteosarcoma subtypes in the European Osteosarcoma Intergroup patients

Osteosarcoma subtype

\begin{tabular}{lrr}
\hline Common & 404 & $71 \%$ \\
Chondroblastic & 54 & $9 \%$ \\
Fibroblastic & 53 & $9 \%$ \\
Teleangiectatic & 10 & $2 \%$ \\
Osteoclast rich & 11 & $2 \%$ \\
Other & 36 & $6 \%$ \\
Not subtyped & 2 & \\
Total & 570 & \\
\hline
\end{tabular}

criteria we used to compose our study group, in a sense, arbitrary. Still, any Li-Fraumeni syndrome patient has a $70 \%$ chance of developing any primary invasive cancer (excluding cancer of the skin) before the age of 45 years. ${ }^{23}$ By selecting all patients with the development of a primary tumour before the age of 46 years after selecting all patients with a known history of retinoblastoma or a malignancy of the skin before the age of 44 years we believe, we extracted those individuals highly suspected for membership of a LiFraumeni family.

As for osteosarcoma subtypes in patients in our syndrome-suspected study group, there appears to be a large fraction of rare osteosarcoma subtypes in this group. In all, 70\% of all reviewed osteosarcomas in the syndromesuspected study group were other than common-type osteosarcoma. When cases without a relation to treatment were left out, all remaining patients had non-common subtype. Of the 81 patients who developed an osteosarcoma after treatment for cancer in a study of the late effects study group by Newton, ${ }^{41} 57 \%$ of the patients treated with radiation therapy had a common type of osteosarcoma. In contrast, in the patients not treated with radiotherapy, the common type was most frequent (90\%). In this study, there were also five patients with a family history of cancer. Half of these patients had an osteosarcoma of common type and half of another subtype. Thus, the histological subtyping of osteosarcomas might be predictive as a diagnostic tool in the process of detecting patients with a yet undiagnosed familial predisposition for the development of cancer, more specific yet undiagnosed cases of Li-Fraumeni syndrome. Osteosarcoma can be the first or even the only primary tumour to occur not only in the individual patient, but also in a family with no indication for Li-Fraumeni syndrome at the moment of osteosarcoma diagnosis in one of their offspring. ${ }^{42}$ This has been further proven by the detection of the Li-Fraumeni syndromespecific p53 germ cell mutation ${ }^{43}$ in a number of cases of multiple malignant neoplasms in children and young adults without a family history of Li-Fraumeni syndrome. ${ }^{44}$

The absolute numbers we presented here are most likely underestimated. Registration in PALGA covers all the 
departments of pathology in the Netherlands only since 1990. The overall survival for osteosarcoma patients is around 55\% and patients diagnosed with osteosarcoma in the later years have not yet developed their possible second tumour. This might mean that the initial number of patients suspected for Li-Fraumeni syndrome in our study is smaller than the actual amount of Li-Fraumeni syndrome patients in the total osteosarcoma patient population.

We conclude that although osteosarcoma is a rare tumour, an osteosarcoma patient has a relative risk of 2.4 (95\% confidence interval $1.88-3.07)$ to develop another malignancy. Women are more susceptible than men to osteosarcoma after any other primary tumour. Two of the osteosarcoma patients had retinoblastoma. At a minimum, $1.2 \%$ of the osteosarcoma patients are suspected for a hereditary cancer syndrome, and a noncommon subtype of osteosarcoma in a young patient raises the possibility of an individual to belong to a family with hereditary cancer syndrome.

\section{Acknowledgements}

The contribution to this study of the Dutch national pathology database 'Stichting PALGA' and the continuous support of the European Osteosarcoma Intergroup (EORTC/MRC) data centres are fully acknowledged. PCW Hogendoorn is recipient of a research grant of the Optimix foundation for fundamental research. We greatly thank Drs J Calame, MLF van Velthuysen, WM Spliet, $R$ Parren, G Burger, $H$ Bril, M Nap, G Verdonk, N Hoftstee, JE Broers, M van Dijk, JC van Linden, J Lagendijk, H Ruitenberg, J Elbers, E Boers, $R$ Schapers, $F$ van Kemenade, W Oosterhuis, F Bot, Dhr Wegener, L Ceelen, T Manschot and $C$ Diepenbrouck, who contributed to the study by sending their material for review. We also thank $T$ De Craen for help with the statistical analysis. This study has been presented at the 15th Annual Meeting of the European Musculo-Skeletal Society.

\section{References}

1 Dorfman HD, Czerniak B: Bone tumors, 1st edn. St. Louis: Mosby, 1997.

2 Huvos AG: Bone tumors. Diagnosis, treatment and prognosis. 2nd edn. Philadelphia: WB Saunders, 1991.

3 Unni KK: Dahlin's bone tumors: general aspects and data on 11,087 cases, 5th edn. Philadelphia: Lippincott-Raven, 1996.

4 Cullen JW: Second malignant neoplasms in survivors of childhood cancer. Pediatrician 1991;18: 82-89.

5 Meadows AT: Second tumors. Eur J Cancer 2001; 37: 2074-2079.

6 Abramson DH, Ellsworth RM, Zimmerman LE: Nonocular cancer in retinoblastoma survivors. Tr Am Acad Ophtholmol \& Otol 1976; 81: 454-457.

7 Abramson DH, Ellsworth RM, Kitchin FD: Osteogenic sarcoma of the humerus after cobalt plaque treatment for retinoblastoma. Am J Ophthalmol 1980; 90: 374-376.

8 Abramson DH, Ellsworth RM, Kitchin FD, Tung G: Second nonocular tumors in retinoblastoma survivors. Are they radiation induced. Ophthalmology 1984; 91: 1351-1355.

9 Draper GJ, Sanders BM, Kingston JE: Second primary neoplasms in patients with retinoblastoma. Br J of Cancer 1986; 53: 661-671.
10 Hawkins MM, Draper GJ, Kingston JE: Incidence of second primary tumours among childhood survivors. Br J Cancer 1987; 56: 339-347.

11 Meadows AT, Baum E, Fossati-Bellani F et al: Second malignant neoplasms in children: an update from the late effects study group. J Clin Oncol 1985; 3: 532-538.

12 Roarty JD, McLean I, Zimmerman LE: Incidence of second neoplasms in patients with bilateral retinoblastoma. Ophthalmology 1988; 95: 1583-1587.

13 Schwartz MB, Burgess LPA, Fee WE, Donaldson SS: Postirradiation sarcoma in retinoblastoma. Induction of predisposition? Arch Otolaryngol, Head Neck Surg 1988; 114: 640-644.

14 Li FP, Fraumeni JF, Mulvihill JJ et al: A cancer family syndrome in twenty four kindreds. Cancer Res 1988; 48: 5358-5362.

15 Strong LC, Stine M, Norsted TL: Cancer in survivors of childhood soft tissue sarcomas and their relatives. J the Nat Cancer Inst 1987; 79: 1213-1220.

16 Goto M, Miller RW, Ishikawa Y, Sugano H: Excess of rare cancers in Werner syndrome (adult progeria). Cancer Epidemiol, Biomarkers Prevention 1996; 5: 239-246.

17 Ishikawa Y, Miller RW, Machinami R, Sugano H, Goto M: Atypical osteosarcomas in Werner syndrome (adult progeria). Jpn J Cancer Res 2000; 91: 1345-1349.

18 Tsuji Y, Kusuzaki K, Kanemitsu K, Matsumoto T, Ishikawa Y, Hirasawa Y: Calcaneal osteosarcoma associated with Werner syndrome. A case report with mutation analyis. J Bone Joint Surg Am Vol 2000; 82A: 1308-1313.

19 Vennos EM, Collins M, James WD: Rothmund-Thomson syndrome: review of the world literature. J Am Acad Dermatol 1992; 27: 750-762.

20 Bacci G, Delepine N, Bertoni $\mathrm{F}$ et al: Predictive factors of histologic response to primary chemotherapy in osteosarcoma of the extremity: study of 272 patients preoperatively treated with high dose methotrexate, doxorubicin and cisplatin. $J$ Clin Oncol 1998; 16: 658-663.

21 Hauben EI, Weeden S, Pringle J, Van Marck EA, Hogendoorn PCW: Does the histological subtype of high-grade central osteosarcoma influence the response to treatment with chemotherapy and does it affect overall survival? A study on 570 patients of two consecutive trials of the European Osteosarcoma Intergroup. Eur J Cancer 2002; 38: 1218-1225.

22 Ferrari S, Bertoni F, Mercuri M et al: Predictive factors of diseasefree survival for non metastatic osteosarcoma of the extremity: an analysis of 300 patients treated at the Rizzoli Institute. Ann Oncol 2001; 12: 1145-1150.

23 Hisada M, Garber JE, Fung CY et al: Multiple primary cancers in families with Li-Fraumeni syndrome. J Nat Cancer Inst 1998; 90: 606-611.

24 Coebergh JW, Neumann HA, Vrints LW, van der Heijden L, Meijer WJ, Verhagen-Teulings MT: Trends in the incidence of nonmelanoma skin cancer in the SE Netherlands 1975-1988: a registry-based study. Br J Dermatol 1991; 125: 353-359.

25 Ewing J: A review of the classification of bone tumors. Bulletin of the American College of Surg 1939; 24: 290-295.

26 Macdonald I, Bud JW: Osteogenic sarcoma I. A modified nomenclature and a review of 118 five year cures. I Am Coll Surg 1943; 77: 413-421.

27 Sim FH, Unni K, Beabout JW, Dahlin DC: Osteosarcoma with small cells simulating Ewing's tumor. J Bone Joint Surg 1978; 61a: 207-215.

28 Simmons CC: Bone sarcoma. Factors influencing the prognosis. Surg Gynecol Obstet 1939; 68: 67-75.

29 Unni K, Dahlin DC, Beabout JW: Periosteal osteogenic sarcoma. Cancer 1976; 37: 2476-2485.

30 Fletcher CDM, Unni KK, Mertens F: World Health Organization Classification of tumours. Pathology and Genetics of Tumours of Soft tissue and bone. Lyon: IARC Press, 2002.

31 Pratt CB, Meyer WH, Luo X et al: Second malignant neoplasms occuring in survivors of osteosarcoma. Cancer 1997; 80: 960-965. 
32 Longhi A, Gamberi G, Bacci G: Brain tumors as second malignant neoplasms in patients with osteosarcoma treated with adjuvant and neoadjuvant chemotherapy: report of 2 cases. J Chemother 2000; 12: 261-262.

33 Ferrari C, Bohling T, Benassi MS et al: Secondary tumors in bone sarcomas after treatment with chemotherapy. Cancer Detection Prevent 1999; 23: 368-374.

34 Nicholson HS, Mulvihill JJ, Byrne J: Late effects of therapy in adult survivors of osteosarcoma and Ewing's sarcoma. Med Pediatric Oncol 1992; 20: 6-12.

35 Green DM, Zevon MA, Reese PJ et al: Second malignant tumors following treatment during childhood and adolescence for cancer. Med Pediatric Oncol 1994; 22: 1-10.

36 Hawkins MM, Wilson LM, Burton HS et al: Radiotherapy, alkylating agents, and risk of bone cancer after childhood cancer. I Nat Cancer Inst 2001; 88: 270-278.

37 Li FP: Second malignant tumors after cancer in childhood. Cancer 1977; 40: 1899-1902.

38 Neglia JP, Friedman DL, Yasui Y et al: Second malignant neoplasms in five year survivors of childhood cancer: childhood cancer survivor study. I Nat Cancer Inst 2001; 93: 618-629.
39 Hansen MF, Koufos A, Gallie BL et al: Osteosarcoma and retinoblastoma: a shared chromosomal mechanism revealing recessive predisposition. Proc Nat Acad Sci 1985; 82: 6216-6220.

40 Dryja TP, Rapaport JM, Epstein J et al: Chromosome 13 homozygosity in osteosarcoma without retinoblastoma. Am J Hum Genet 1986; 38: 59-66.

41 Newton WA, Meadows AT, Shimada H, Bunin GR, Vawter GF: Bone sarcomas as second malignant neoplasms following childhood cancer. Cancer 1991; 67: 193-201.

42 Porter DE, Steel CM, Cohen BB, Wallace MR, Reid R: A significant proportion of patients with osteosarcoma may belong to Li-Fraumeni cancer families. J Bone Joint Surg (Br) 1992; 74: 883-886.

43 Malkin D, Li FP, Strong LC et al: Germline p53 mutations in a familial syndrome of breast cancer, sarcomas and other neoplasms. Science 1990; 250: 1233-1238.

44 Malkin D, Jolly KW, Barbier N et al: Germline mutations of the p53 tumor-suppressor gene in children and young adults with second malignant neoplasms. N Engl J Med 1992; 326: 1309-1315. 